\title{
ETYKA TROSKI A GOSPODARKA PRZYSZŁOŚCI
}

\author{
ZOFIA ŁAPNIEWSKA
}

\begin{abstract}
Abstrakt: Przez dziesięciolecia teorie ekonomiczne zmieniały się pod wpływem wydarzeń historycznych oraz turbulencji gospodarczych, za każdym razem miały one jednak konkretne przełożenie na życie społeczeństw. Dziś, gdy teorie neoliberalne przestaja cieszyć się uznaniem, rozwarstwienie pomiędzy najbogatszymi i najuboższymi postępuje prawie geometrycznie, a rozwój technologii sprawia, że drastycznie zmieniają się warunki pracy, potrzebne są nowe wizje gospodarki przyszłości, w której każdy mógłby znaleźć swoje miejsce i godnie żyć. Moja propozycja wiąże się z oparciem gospodarki na etyce troski, który to argument prezentuję w niniejszym artykule. W jego wstępie przyglądam się zachodzącym zmianom gospodarczym. Następnie przybliżam znaczenie etyki troski, a także opieki niezbędnej do rozwoju i reprodukowania się społeczeństw jako głównych ram przyjętych w dalszych rozważaniach nad gwarancja zatrudnienia oraz bezwarunkowym dochodem podstawowym, którym poświęcone są kolejne części artykułu. Analizy tych teorii, przeprowadzone $z$ feministycznego punktu widzenia, wzbogacone zostaną także o propozycje dodatkowych rozwiązań, które wychodzą poza obowiązujący dziś paradygmat wzrostu.
\end{abstract}

Słowa kluczowe: etyka troski, ekonomia feministyczna, opieka, bezwarunkowy dochód podstawowy, gwarancja zatrudnienia, gospodarka przyszłości. 


\section{Wstęp}

Roztaczając utopijne, a więc i dystopijne wizje dotyczące gospodarki najbliższych lat - każdą dynamikę bowiem wyznaczaja zawsze dwukierunkowe zmiany (Polanyi 2010, 155) - możemy zauważyć, że prognozy dotyczące tworzenia stałych miejsc pracy produkcyjnej maluja przyszłość raczej w czarnych barwach. Jesienią zeszłego roku gazeta The Telegraph przedstawiła nowego robota, który bez pomocy człowieka potrafi uszyć t-shirt (McGoogan 2016). Z jednej strony, roboty w halach produkcyjnych napawają optymizmem, gdyż zastapić moga głównie kobiety (a także dzieci) w tzw. sweatshops, pracujące w warunkach uragających ludzkiej godności, narażające swoje życie i zdrowie. Z drugiej strony, za sprawą robotyzacji ogromne masy ludzi stracić mogą dostęp nawet do tak nisko opłacanej pracy produkcyjnej, będącej często ich jedynym źródłem dochodu. Jednocześnie głównym problemem krajów globalnej Północy pozostaje nadprodukcja i „gospodarka nadmiaru” raczej niż „niedoboru”. Technologie pozwalaja podwoić, a nawet potroić wydajność, lecz nadwyżkowe towary nie znalazłyby nabywców - zjawisko to nazwane jest w ekonomii „luką popytową”. Z pewnością postęp technologiczny obejmie także transport lądowy, powietrzny i wodny: w przyszłości nie będa potrzebni kierowcy, a usługa przemieszczenia się z miejsca na miejsce będzie ważniejsza niż posiadanie samochodu osobowego (ich produkcja spadnie). Pełniejszej automatyzacji będą ulegać kolejne gałęzie przemysłu, i choć będą one nadal generowały zyski, praca ludzka będzie dla nich coraz mniej użyteczna. Z uwagi na dzisiejszy rozwój rynków finansowych, gdy handel derywatywami jest pięciokrotnie większy od globalnego PKB (Appadurai 2016), można by przyjać, że to w tej branży będą tworzone nowe miejsca pracy. Niemniej jednak widmo kolejnego kryzysu przewidywanego przez ekonomistów również tę opcję stawia pod znakiem zapytania. Pozostaja inne usługi, w tym opieka, na którą wskazują ekonomistki feministyczne - i tu szanse na rozwój rynku pracy są znaczne, choć praca ta wyceniana jest bardzo nisko.

W związku z powyższymi rozważaniami pojawia się problem dotyczący postulatów gwarancji zatrudnienia (GZ), bowiem wszystko wskazuje na to, że miejsc pracy nadal będzie ubywać, a jak szacuje Ogólnopolskie Porozumienie Związków Zawodowych, dziś w kraju brakuje ich dla 2,3 mln ludzi, czyli prawie $5 \mathrm{mln}$, licząc polską emigrację (OPZZ 2017). Wobec tego pracą trzeba będzie zacząć się dzielić, dążąc jednocześnie do wprowadzenia dwudziestojednogodzinnego tygodnia roboczego (NEF 2010), co szerzej omówię w dalszej części artykułu.

Jednocześnie możemy zauważyć, że świat, a w szczególności kraje globalnej Północy ${ }^{1}$ w swojej historii nigdy nie były tak bogate. I prawdopodobnie już nigdy nie będą,

\footnotetext{
1 W tym artykule skupiam się przede wszystkim na kontekście Polski i pozostałych krajów wysoko rozwiniętych, które pomimo różnic gospodarczych, czyli odmiennych typów uwarunkowań kapitalistycznych
} 
bo to, że pozostała część świata będzie zwiększać konsumpcję i inwestycje, nie oznacza wcale, że zyskają na tym kraje wysoko rozwinięte. Raczej będą one musiały powoli ograniczać swoje potrzeby konsumpcyjne, zwracając się ku innemu paradygmatowi gospodarczemu, np. ku idei post-wzrostu (ang. degrowth) (zob. D'Alisa, Demaria i Kallis 2015). Obecny dobrobyt krajów należących do Organizacji Współpracy Gospodarczej i Rozwoju (OECD), w tym Polski, zdecydowanie stanowi argument za wprowadzeniem bezwarunkowego dochodu podstawowego (BDP) i tym samym za równiejszą redystrybucją dochodów publicznych, przy jednoczesnym dawaniu obywatelkom i obywatelom stabilności, poczucia własnej godności i redukcji ich lęków egzystencjalnych, gdy o stałą pracę coraz trudniej. To rozwiązanie omówię z feministycznego punktu widzenia, odnosząc się między innymi do normatywnych zasad równości płci wyznaczonych przez Nancy Fraser (1994).

Uważam, że w przypadku obydwu programów, zarówno gwarancji zatrudnienia, jak i bezwarunkowego dochodu podstawowego, które to rozwiązania zdecydowanie należą do polityki gospodarczej przyszłości, fundamentalnym założeniem powinna być etyka troski (Tronto 1987) o innych ludzi oraz - szerzej - o naturę czy inne gatunki planety, w myśl koncepcji posthumanizmu (Barad 2003, Braidotti 2014). Jest to założenie zgodne z polityką prefiguratywna (Epstein 2002, Cornish i in. 2016), do której odwołuja się światowe ruchy społeczne i która zakłada, że należy przemyśleć i zmieniać świat tak, aby był lepszym miejscem do życia dla wszystkich. Te wyobrażenia przyszłości oraz aktywne działania podejmowane na rzecz zmiany społecznej oparte są na dążeniach do absolutnej równości, wzajemnym szacunku, wolności i sprawiedliwości, a przy tym uwzględniają znaczenie emocji i relacji międzyludzkich w dążeniu do dobrostanu. Do tych obszarów refleksji będę odwoływała się szerzej, budując argumentację na rzecz gwarancji zatrudnienia oraz bezwarunkowego dochodu podstawowego.

W pierwszej części niniejszego artykułu wyjaśniam znaczenie etyki troski w odniesieniu do badań prowadzonych przez ekonomistki feministyczne, które to badania bezpośrednio związane są z opieką i nawiązują do postulatów gwarancji zatrudnienia przedstawionych w części drugiej. Trzecia część dotyczy kwestii bezwarunkowego dochodu podstawowego jako progresywnego rozwiązania gospodarczego, eksperymentalnie wdrożonego w jednym i rozważanego w trzech kolejnych krajach. Argumentacja za wprowadzeniem tego typu mechanizmu redystrybucji przedstawiona zostanie w świetle

(ang. variegated capitalism - zob. Peck i Theodore 2007), są w dużej mierze do siebie gospodarczo, społecznie i kulturowo zbliżone. Nie oznacza to, że podobne rozważania w zakresie opieki, gwarancji zatrudnienia i bezwarunkowego dochodu podstawowego nie dotyczą pozostałych krajów świata, z pewnością jednak powinny one same zabrać głos w tej kwestii. 
postulatów równości płci. W podsumowaniu powracam do problemu wyobrażonej przyszłości gospodarczej, nawiązując także do koncepcji przedstawionych w całym tekście.

\section{Etyka troski i odniesienia do ekonomii feministycznej}

Etyka troski została przedstawiona przez amerykańską politolożkę Joan Claire Tronto jako „zespół wrażliwości, który powinna rozwinąć każda moralnie dojrzała osoba” (Tronto 1987, 662). Rozwija ona myśl Carol Gilligan (1977), która wskazywała, że opieka (troska), przypisywana przede wszystkim kobietom, powinna być elementem moralności traktowanym na równi ze sprawiedliwością, stereotypowo przypisywaną mężczyznom. Tronto idzie dalej, argumentując, iż „brak doświadczeń związanych z opieką sprawia, że uprzywilejowani mężczyźni stają się moralnie zdeprawowani" (Tronto 1987, 652). Według tej autorki konkretna osoba może rozwinąć wspomnianą wrażliwość, jeśli zarówno opiekuje się ona innymi, jak i doświadcza opieki innych nad soba. Choć opieka jest często postrzegana jako prywatna sfera życia, to liczne badania ujawniaja jej kolosalne znaczenie dla gospodarki w sensie produkcyjnym i reprodukcyjnym - oraz dla rozwoju społeczeństw i stwarzania szans na dobre życie dla wszystkich (Budlender i Sharp 1998). Dlatego, jak postuluje Clare Ungerson (1995), w przypadku opieki podział na prywatne i publiczne jest sztuczny i krzywdzący zarówno dla kobiet, jak i dla mężczyzn, należałoby go zatem znieść i myśleć o opiece szerzej, w ramach obywatelstwa. Dodatkowo ekonomistki feministyczne wskazuja, że równiejszy podział opieki pomiędzy kobiety i mężczyzn może doprowadzić do wzrostu jakości życia zarówno jednych (zyskujących więcej czasu na inne zajęcia czy odpoczynek), jak i drugich (budujących tym samym relacje z bliskimi) (Esplen 2009). Jednocześnie ekonomia feministyczna, podobnie jak inne nurty ekonomii heterodoksyjnej (np. postkeynesizm, instytucjonalizm czy szkoły marksistowskie), wskazuje, że należy odejść od etosu indywidualizmu „ekonomicznego człowieka” (bomo oeconomicus) dokonującego racjonalnych wyborów i maksymalizującego własne korzyści, i zwrócić się w kierunku gospodarki społecznej oraz kolektywnej, bazującej na trosce, lojalności, wzajemności, solidarności i równych prawach (Phillips 2007). Postrzeganie ludzi przez pryzmat ich relacji z innymi, w tym relacji opieki na każdym etapie życia, zdecydowanie wykracza poza definicję natury ludzkiej przyjęta przez główne nurty ekonomii - te bowiem uznaja, że człowiek zawdzięcza wszystko wyłącznie sobie (ang. self-made man). Etyka troski zakłada, że poczucie odpowiedzialności za innych w budowanych relacjach stwarza porządek społeczny, który nie pozwala na pełne korzystanie z praw indywidualnych. Rosi Braidotti nazywa to „śmiercia ego" (Braidotti 2006, 155).

Założenia etyki troski zarówno są powiązane z naszymi osobistymi doświadczeniami w relacjach z bliskimi osobami, jak i wskazują na szersze ramy społeczne, które w tym 
artykule odnoszą się do wizji gospodarki przyszłości. W kolejnych latach właśnie przyjęcie tych założeń może okazać się niezbędne do wprowadzenia bezwarunkowego dochodu podstawowego (w trosce o innych, a w szczególności o defaworyzowane grupy społeczne), utworzenia nowych miejsc pracy w sektorze opieki lub zmiany całego paradygmatu makroekonomicznego na taki, w którym prace reprodukcyjne byłyby wartościowane podobnie do prac produkcyjnych. Do tego ostatniego zagadnienia nawiazzuje Marylin Power w szkicu metodologii ekonomii feministycznej, wskazując na kwestie, które badaczki i badacze powinni uwzględniać, projektując swoje analizy. Są to: uznanie i włączenie opieki oraz nieodpłatnej pracy do podstawowych aktywności ekonomicznych; potraktowanie dobrostanu jako miary sukcesu ekonomicznego; analizowanie gospodarczych, politycznych i społecznych procesów oraz relacji władzy; włączenie do analizy jako jej nieodzownej części celów i wartości etycznych; badanie różnic klasowych, rasowo-etnicznych i innych charakterystyk wpływających na wyniki prowadzonych badań (Power 2004, 3). Założenia te można potraktować jako ramy dla wszelkich rozważań nad zmianami czy eksperymentami społeczno-gospodarczo-politycznymi, które powinny być brane pod uwagę przy planowaniu i opracowywaniu konkretnych rozwiązań oraz strategii. Tronto traktuje etykę troski szerzej, suponując, że „społeczeństwo oparte na trosce byłoby prawdopodobnie mniej przemocowe, naładowane wściekłością i nieszczęśliwe niż wiele społeczeństw jest obecnie" (Tronto 1995, 148). Opieka nad dziećmi, osobami starszymi i innymi osobami zależnymi, a w różnych kulturach (np. w Mongolii) także troska o osoby z tej samej miejscowości, z tej samej klasy czy szkoły, oraz współdziałanie i wyświadczanie szeregu przysług pozwala mieszkankom i mieszkańcom na budowanie „siły powodzenia” i „siły życiowej” opartej na więziach (Rakowski 2016, 100). W tym kontekście opieka przestaje być, jak zdaje się wielu osobom, jedynie przykrym obowiązkiem i przemienia się w „fortunę i bogactwo nagromadzone jako sieć relacji” (Rakowski 2016, 100-101). Opieka ma jednak różne formy i nie dotyczy wyłącznie kręgu osób bliskich, może być także świadczona odpłatnie i traktowana jako praca, o czym więcej poniżej.

\section{Wymykająca się utowarowieniu opieka a podział pracy}

Bezsprzecznie założenia etyki troski odnoszą się do problemu opieki jako aktywności społecznej. Ungerson dzieli opiekę na trzy kategorie: spontaniczna, nieregularna opiekę oferowaną wewnątrz danej społeczności; świadczenie usługi opieki jako pracy, gdy osoba ja otrzymująca jest zależna od osoby opiekującej się nią; osobista usługa oparta na nierównej relacji pomiędzy dwiema osobami, gdy jedna z nich, ta o wyższym statusie, jest w stanie troszczyć się sama o siebie (Ungerson 1990, 14-15). Zarówno status osoby wymagającej opieki, jak i świadczącej opiekę jest nieodzownie związany z relacjami władzy i tym samym 
stanowi istotne zagadnienie $\mathrm{z}$ zakresu ekonomii feministycznej (Hartmann 1976). Asymetryczny podział władzy może być szczególnie dotkliwy dla osoby bardziej potrzebującej opieki, dlatego w takiej relacji nie wszystkim osobom zagwarantowane zostanie osiągnięcie dobrostanu (Sen 1993). Nierówny podział władzy nie dotyczy tylko sektora opieki, lecz także publicznych i prywatnych instytucji wraz $z$ nadawanymi przez nie przywilejami czy ich stosunkiem do odbiorców świadczonych przez nie usług (Fraser 1990). Dotyczy także stratyfikacji obecnej w danych społeczeństwach, poziomu ignorancji czy wzajemnego szacunku (Benería 2003). Wreszcie to również sprawa samych gospodarstw domowych, w których panuje określona władza (i przemoc) ekonomiczna (Cantillon 2013). Zaznaczyć trzeba, że osoby, które powinny zabierać głos w sprawie opieki, często nie są reprezentowane lub są nierówno traktowane, np. dlatego, że posługują się prostym językiem lub mają niższy status ekonomiczno-społeczny. Fraser wskazuje, że „teoria sprawiedliwości musi być trójwymiarowa, obejmując polityczny wymiar reprezentacji, ekonomiczny wymiar dystrybucji oraz kulturowy wymiar uznania" (2014, 260). Te trzy elementy są bardzo istotne z punktu widzenia założeń dotyczących nowej gospodarki, opartej właśnie na etyce troski.

Zagwarantowanie równego dostępu do usług i wysokiego standardu opieki, niezbędnej ludziom do łączenia ich obowiązków opiekuńczych z pracą zawodową na różnych etapach życia - etapy te wraz ze zmieniającymi się potrzebami opieki nazywane sa „pejzażami opieki" (ang. caringscapes - zob. McKie, Gregory i Bowlby 2002) - byłoby pierwszym krokiem ku realizacji teorii sprawiedliwości Fraser. Usługi te, niezależnie od tego, czy oferowane przez instytucje państwowe, czy prywatne, wymagają od osób je świadczących szczególnych i wyspecjalizowanych umiejętności, tj. dbałości o potrzeby osób, którymi się opiekują, brania odpowiedzialności za swoje działania, określonych uprawnień oraz zdolności do adekwatnego odpowiadania na potrzeby osób wymagających opieki (Fisher i Tronto 1990). Oczekiwania te jednoznacznie przemawiają za waloryzacja wynagrodzeń za usługi opiekuńcze (przynajmniej do poziomu średniej krajowej) i traktowaniem opiekunów jako pracowników tak samo odpowiedzialnych i wyspecjalizowanych jak pracownicy branż produkcyjnych gospodarki.

Z uwagi na fakt, że opieki na świecie brakuje, a w krajach wysoko rozwiniętych dotyczy to szczególnie opieki nad osobami starszymi, z czasem powstał rynek opieki, który w pewnym sensie ją utowarowił. Jak wskazuje Virginia Held (2006), na rynku tym rządza prawa skuteczności i wydajności, co sprowadza debatę nad usługami opiekuńczymi do rachowania ich kosztów. Tak też postrzegana jest opieka przez wiele osób nielegalnie zatrudniających migrantki i migrantów, często łamiąc ich podstawowe prawa (np. zabierając im paszporty, odmawiając prawa do prywatności i czasu wolnego, obarczając pracą ponad siły, która przybiera formę współczesnego niewolnictwa) (Ehrenreich i Hochschild 2004). Najczęściej 
migrantki pozostawiaja w swoich krajach osoby wymagające opieki (zjawisko znane pod angielską nazwą care drain) i uczestnicząc w globalnych łańcuchach opieki, wykonują odpłatnie pracę w krajach wysoko rozwiniętych.

Tymczasem prowadzone w krajach OECD analizy i badania dotyczące wzrostu zatrudnienia w sektorze opieki - zmiany zbieżnej z postulatami zwolenników gwarancji zatrudnienia (Tcherneva i Wray 2005) - wskazuja, że to państwo powinno tworzyć nowe miejsca pracy, stymulując rynek. Dodatkowo, przeprowadzając symulację wzrostu zatrudnienia w sektorze opieki, tak aby efektywnie odpowiadać na zapotrzebowanie na nią, nasza grupa badawcza wykazała dla siedmiu krajów OECD, że inwestycje w ten sektor w równym, a nawet większym stopniu niż w sektor budowlany wpływają na wzrost gospodarczy (De Henau i in. 2016). Jest to ważna obserwacja, którą warto uwzględnić przy projektowaniu polityki gospodarczej podczas kryzysów lub spowolnień wymagających większej interwencji państwa w rynek. Inwestycja środków publicznych w tzw. infrastrukturę społeczną nie tylko wpłynęłaby na wzrost zatrudnienia w tym sektorze, lecz także dzięki efektom pośrednim i indukowanym przyczyniłaby się do wzrostu zatrudnienia w innych sektorach gospodarki. W przypadku efektów pośrednich byliby to np. dostawcy produktów i usług do przedszkoli, domów opieki, świetlic itd., zaś w przypadku efektów indukowanych pracownicy branż odpowiadających na wzrost konsumpcji w gospodarstwach domowych.

Dobrze wynagradzana praca opiekuńcza z pewnością przyciąnęłaby pracowników, gdyż jak każda inna praca, na co zwracają uwagę zwolennicy GZ z Levy Institute, daje ona satysfakcję, poczucie obywatelstwa, wzajemności, zaangażowania czy spełnionego obowiązku społecznego. Pavlina R. Tcherneva i L. Randall Wray wskazują także na komplementarność propozycji gwarancji zatrudnienia i dochodu obywatelskiego, gdy ten drugi byłby oferowany szczególnie osobom zależnym i niemogącym podjąć pracy najemnej, choć tym samym przestałby on mieć charakter bezwarunkowy (Tcherneva i Wray 2005, 126). Autorzy w swoim artykule dokonują szczegółowych analiz argentyńskiego programu zatrudnienia Jefes de Hogar (hiszp. „głowa gospodarstwa domowego”), używając wskaźników makroekonomicznych i przedstawiając szczegółowy profil beneficjentów, a także zmiany zachodzące w czasie trwania programu (np. odpływ pracowników do sektora prywatnego). W ramach tego programu oferowana była praca czasowa (często sezonowa) z wynagrodzeniem godzinowym oraz dodatkowymi świadczeniami (np. ubezpieczeniem zdrowotnym), a rekrutacja była dobrowolna. Taka forma zatrudnienia mogłaby przekonać niektórych przeciwników GZ, którzy najczęściej oponuja przeciwko przymusowi pracy stojącemu w sprzeczności z zasadą korzystania z osobistych wolności - niskim standardom zatrudnienia, niskim wynagrodzeniom niepozwalającym na awans społeczny, niesatysfakcjonującym formom pracy, które uniemożliwiaja pracownikowi rozwój (Standing 2005) oraz kontroli państwowej nad życiem mieszkańców i opresji władzy. W latach 
intensywnego rozwoju przemysłu (w szczególności elektronicznego) Herbert Marcuse przedstawił następujące rozważania na temat rynku pracy:

[g]dyby jednostka nie była już zmuszana do sprawdzania na „rynku” siebie, jako wolnego podmiotu ekonomicznego, zniknięcie tego rodzaju wolności byłoby jednym z największych osiagnięć cywilizacji. Technologiczny proces mechanizacji i standaryzacji mógłby skierować indywidualną energię do jeszcze nie zaznaczonej na mapie dziedziny wolności poza koniecznością (Marcuse 1991, 18-19).

Dziś słowa Marcusego mogłyby być odczytane jako ukłon w stronę bezwarunkowego dochodu podstawowego, wypłacanego wszystkim, a nie tylko osobom zależnym, czyli będącego droga wyjścia poza pracę najemną. Z pewnością dodatkowym argumentem na rzecz tego rozwiązania, poza znikającymi miejscami pracy produkcyjnej, o których pisałam we wstępie, są także analizy Thomasa Piketty'ego (Piketty 2015). Zestawiając dane z pięćdziesięciu krajów na przestrzeni ponad trzystu lat, autor wskazał, że zarobki uzyskane z pracy produkcyjnej nigdy nie będą tak wysokie jak zyski z kapitału, a dalszy wzrost nierówności jest (i pozostanie) nieodłączną cechą systemu kapitalistycznego. Na całym świecie rośnie też liczba „pracujących biednych”, którzy pomimo pracy w pełnym wymiarze nie są w stanie żyć w godnych warunkach.

Polscy pracodawcy, jak wskazują dane OECD, w porównaniu z pracodawcami $\mathrm{z}$ innych europejskich krajów w nieznacznym stopniu dzielą się zyskami z pracownikami, a udział płac w produkcie krajowym brutto od lat maleje, mimo że produktywność jest coraz wyższa (OECD 2017). Przykładowo prezes spółki Comarch S.A. zarabia miesięcznie 500 razy więcej od pracowników o najniższym wynagrodzeniu w jego firmie (Sroczyński 2015, 133146). Gdyby te nierówność ograniczyć, choćby do zaproponowanej w Szwajcarii maksymalnie dwunastokrotnej różnicy płac w przedsiębiorstwie, to nie tylko stworzono by polskim pracownikom godne warunki życia, lecz także mogliby oni pracować mniej. Z tym wiąże się postulat New Economics Foundation (NEF), zgodnie z którym dwudziestojednogodzinny wymiar tygodniowej pracy powinien być docelowym „etatem” (NEF 2010). NEF argumentuje, że dwadzieścia jeden godzin pracy najemnej umożliwiłoby nam zmierzenie się ze współczesnymi problemami takimi jak: przepracowanie, wypalenie zawodowe, bezrobocie, nadmierna konsumpcja, nierówności, niski standard życia oraz brak czasu na prowadzenie zrównoważonej egzystencji, troskę o innych i odczuwanie radości z życia (NEF 2010). NEF wzywa także do przewartościowania tego, co uznajemy za pracę i opłacamy, dowartościowania opieki i innych nieodpłatnych prac lub prac wykonywanych nieformalnie w lokalnych społecznościach oraz na rzecz osób bliskich, a także wszelkich aktywności związanych z zachowaniem zasobów planety, dobrostanu innych gatunków, co wiąże się $z$ ideami posthumanizmu, do których nawiązywałam we wstępie. NEF przewiduje szereg 
trudności, które napotkamy w czasie drogi do tak zdefiniowanego etatu, włączając w to: opór ze strony pracodawców w związku ze zmniejszonym wymiarem pracy indywidualnej oraz możliwymi problemami $z$ pozyskaniem wykwalifikowanych i lubiących swoja pracę pracowników; opór ze strony samych pracowników oraz związków zawodowych, obawiających się wpływu tych zmian na obniżenie wynagrodzeń; wreszcie sprzeciw polityków, którzy są lobbowani przez wszystkie wymienione grupy.

Idea skróconego czasu pracy została opisana przez niemiecką socjolożkę Friggę Haug (2011). Autorka, odwołując się do Karola Marksa, wychodzi z założenia, że „rozwój każdego jest warunkiem koniecznym dla rozwoju wszystkich” (Haug 2011, 1). Twierdzi ona, że zadań i niezbędnych prac do wykonania jest aż nadto, a zatem nie jest potrzebna dodatkowa podaż pracy. Proponuje ona w zamian sprawiedliwą redystrybucję pracy, która opierałaby się na podziale wszystkich aktywności pomiędzy osoby zdolne do pracy w czterech czterogodzinnych blokach na dobę. Byłyby to: zatrudnienie, prace reprodukcyjne, rozwój osobisty i działalność polityczna. Oczywiście jest to pewien „kompas”, nie zaś imperatyw w rozważaniach nad bardziej sprawiedliwą gospodarką. Tym samym zarówno kobiety, jak i mężczyźni, a także osoby wymykające się binarnym podziałom genderowym, byłyby zaangażowane w opiekę nad innymi w ramach prac reprodukcyjnych, w równym stopniu i na równych zasadach uczestniczyłyby w rynku pracy, miałyby czas na rozwój, odpoczynek i zaangażowanie polityczne. Ten podział bezsprzecznie dawałby kobietom szanse na większą aktywność w innych obszarach życiowych niż tylko w pracy najemnej i nieodpłatnych pracach wykonywanych w gospodarstwie domowym, gdyż - jak wskazują badania - dotąd to głównie na nich spoczywał ciężar wykonywania tych drugich (wycenia się, że nieodpłatna praca mężczyzn wykonywana na rzecz gospodarstwa domowego w Polsce warta jest średnio jedynie 58 procent pracy wykonywanej nieodpłatnie przez kobiety [GUS 2015]).

Ostatnim rozwiązaniem, które pragnę tu omówić w zakresie podziału pracy, jest koncepcja „zrównoważonych pakietów pracy” zaproponowana przez amerykańskiego ekonomistę Michaela Alberta (2007). Dzieli on prace na takie, które wymagają kreatywności, są rozwojowe i satysfakcjonujące, oraz takie, które są monotonne, automatyczne, ale muszą zostać wykonane. Wedle autora sprawiedliwość społeczną gwarantowałby podział całej istniejącej pracy na pakiety, rozdzielone następnie pomiędzy osoby zdolne do pracy. W takim wypadku prace najniżej opłacane, mechaniczne, a często pogardzane, zniknęłyby z rynku, bo każda osoba podejmująca wymarzona i jednakowo upodmiotawiająca pracę otrzymywałaby w pakiecie także zadania z zakresu np. sprzątania, kopania rowów czy dozorowania. Dla nas, ekonomistek feministycznych, ważna w tym wypadku byłaby zmiana ram makroekonomicznych, w których uwzględniono by także prace opiekuńcze oraz inne prace domowe i reprodukcyjne, które znalazłyby miejsce we wskazanych przez Alberta 
pakietach. Dziś możemy także zauważyć, że prace najbardziej nieprzyjemne i niewdzięczne są stopniowo automatyzowane, zatem w przyszłości być może roboty wyręczą nas w sprzątaniu, lecz nie zastąpią nas w relacjach opiekuńczych.

Powyższe rozważania wskazuja jasno, że praca może być różnie definiowana i nie jest jednakowo atrakcyjna. Stąd argumenty zwolenników GZ niekoniecznie przemawiaja do wszystkich, pomimo wynikających z podejmowania pracy zalet, takich jak: wzmocnienie pozycji osób wcześniej marginalizowanych, socjalizacja, samorealizacja, użyteczność społeczna i podnoszenie poczucia własnej wartości u pracowników. Jednocześnie zwolennicy BDP przekonują, że to dochód sam w sobie wpływa na poczucie własnej wartości, daje ludziom stabilność i jest upodmiotawiający. Główna przeszkodą w jego wdrożeniu, na którą wskazuja zwolennicy GZ, jest związana z nim (hiper)inflacja. O tym jednak więcej w kolejnej części artykułu.

\section{Feministyczne odniesienia do bezwarunkowego dochodu podstawowego}

Koncepcja bezwarunkowego dochodu podstawowego nieustannie powraca do debaty publicznej od ponad dwóch stuleci, od momentu publikacji broszury Thomasa Paine’a Agrarian Justice w 1797 roku, wywołując żywe dyskusje i fale emocji. Różne podejścia do tego zagadnienia zostały szczegółowo omówione w numerze 2(12)/2014 Praktyki Teoretycznej poświęconym BDP, dlatego w poniższym opracowaniu skupię się raczej na jego feministycznej analizie w odniesieniu do etyki troski i gospodarki przyszłości, nie powtarzając argumentów, które już wybrzmiały.

Z perspektywy opieki i etyki troski najważniejszą kwestia pozostaje pytanie postawione przez Ruth Lister: ,jak zagwarantować uznanie [wagi opieki dla społeczeństwa przyp. ZŁ] bez dalszego zamykania kobiet w rolach opiekunek, które służy ich wykluczeniu z władzy i wpływów wynikających z partycypacji w publicznej sferze gospodarki i polis?” (Lister 1995, 17). Czy faktycznie stanie się tak, że kobiety wycofają się z rynku pracy najemnej, gdy otrzymaja dochód podstawowy? Czy 1000 złotych, który to dochód, jak ostrożnie szacuje Maciej Szlinder, będzie kosztował polski budżet 360 miliardów złotych, plus dodatkowe 23 miliardy na rozszerzenie programu 500+ na wszystkie dzieci (więcej zob. Szlinder 2017), jest kwotą wystarczająco motywująca do odejścia z rynku pracy? Czy podobnego efektu nie miałaby omawiana przez Gośkę Maciejewską i Marcina Marszałka płaca za pracę domową (2014, 174-176), cementująca tym samym tradycyjny podział ról i przestrzeni życiowych (kobiety jako opiekunki i osoby ukryte w przestrzeni prywatnej, mężczyźni jako żywiciele rodzin i osoby aktywne w przestrzeni publicznej)? Wattpliwości te rozwiewa Ingrid Robeyns, odnosząc się zarówno do dotychczas przeprowadzonych badań, jak i do możliwych scenariuszy wpływu takiego świadczenia m.in. na podaż pracy (Robeyns 
2014). Twierdzi ona, że dochód podstawowy prawdopodobnie skłoni kobiety do ograniczenia godzin pracy najemnej, lecz nie spowoduje ich masowego wycofywania się z rynku pracy, gdyż, jak określa to autorka, „[k]apitał ludzki spada, gdy nie jest używany”; dużą rolę odgrywaja tu także inne, niepieniężne korzyści, które kobiety czerpią z pracy zarobkowej. Większe wyzwanie upatruje ona w transformacji tradycyjnych ról płciowych i podziału pracy ze względu na płeć, wskazując na konieczność uzupełnienia świadczenia BDP „innymi środkami polityki społecznej, które wyzwalają kobiety (a także mężczyzn) od oczekiwań co do ról płciowych” (Robeyns 2014). Do tej kwestii nawiązuje także Fraser (1994), która proponuje rozdzielenie świadczenia opieki i kobiet poprzez promowanie modelu „uniwersalnego opiekuna” (ang. universal caregiver), na wzór dyskutowanego „uniwersalnego żywiciela rodziny”, modelu, wedle którego - przynajmniej w założeniu kobiety są traktowane na rynku pracy tak samo jak mężczyźni. Wsparciem dla takiej polityki byłoby np. promowanie elastycznych godzin pracy dla opiekunów, wprowadzenie urlopu ojcowskiego równego macierzyńskiemu oraz wsparcia instytucjonalnego (żłobki, przedszkola, zakłady i centra opieki nad osobami zależnymi). W takiej gospodarce część kobiet mogłaby nawet zwiększyć swój udział w rynku pracy, dysponując dodatkowym czasem, a jednocześnie nie będąc ograniczonymi przez limit dochodów wyznaczający próg uzyskiwania świadczeń, który obowiązuje obecnie.

Caitlin McLean (2015) analizuje wpływ dochodu podstawowego na równość płci, posługując się siedmioma zasadami wyznaczonymi przez Fraser (1994): przeciwdziałania ubóstwu, przeciwdziałania wyzyskowi, równości wynagrodzeń, równości czasu wolnego, równego szacunku, przeciwdziałania marginalizacji i przeciwdziałania androcentryzmowi. BDP odpowiada wszystkim tym założeniom. Wprowadzenie tego transferu pieniężnego zabezpieczyłoby pewien poziom dobrostanu grup najbardziej narażonych na wykluczenie, takich jak samotne matki, migrantki, kobiety wywodzące się z mniejszości etnicznych czy kobiety niepełnosprawne. BDP raczej zapobiegałby ubóstwu niż obniżał jego poziom, gdyż po jego wprowadzeniu, jak już wcześniej wspomniałam, osoby w gospodarstwach domowych nie musiałyby się obawiać przekroczenia progu dochodowego przy podejmowaniu pracy najemnej w szerszym wymiarze. Odbierałby on także władzę „szefom, chłopakom i biurokratom” nad życiem kobiet (Levine 2013), tym samym obniżając ryzyko pozostawania kobiet w relacjach przemocowych i opartych na wyzysku. Kobiety mogłyby również negocjować w swoich relacjach równiejszy podział pracy nieodpłatnej, w tym opiekuńczej, a także mieć większy/równy udział w podejmowaniu decyzji, gdyż dysponując własnymi dochodami i będąc w większym stopniu niezależnymi, mogłyby łatwiej opuszczać niesatysfakcjonujące relacje. Jak podkreślaja Edgar Manjarin i Maciej Szlinder (2016), osoby otrzymujące BDP miałyby także silniejsza pozycje przetargowa w stosunkach z pracodawcami, mogłyby negocjować lepsze warunki pracy z przełożonymi, nie obawiając 
się całkowitej utraty środków do życia. Ten argument może wskazywać przyczynę nieprzyjęcia BDP w Szwajcarii, gdzie opieka i inne prace domowe na szeroką skalę świadczone są przez migrantów za najniższe stawki albo na czarnym rynku. BDP obniżyłby także poziom stresu kobiet i mężczyzn ubiegających się o zasiłki i świadczenia od państwa, procedury te często bywają bowiem poniżające, związane są z przemocą i kontrola ze strony instytucji oraz urzędników państwowych. Zwolennicy BDP podkreślają również, że otrzymywanie dochodu nie wykluczałoby korzystania z bezpłatnych dóbr i usług, dzięki którym beneficjentki i beneficjenci mogliby godnie żyć, takich jak bezpłatna opieka zdrowotna, bezpośrednie zaopatrzenie w żywność i ubrania czy przyznawanie mieszkań dla osób potrzebujących (Alexander 2015). BDP przemawiałby także za wyrównaniem wynagrodzeń pomiędzy kobietami i mężczyznami, gdyż lepsza pozycja negocjacyjna kobiet w kwestii podziału pracy nieodpłatnej może znaleźć odbicie w równej dyspozycyjności kobiet i mężczyzn na rynku pracy, podobnej możliwości podnoszenia kwalifikacji, brania odpowiedzialności a także przyjmowania awansów. Tym samym tropem podąża argumentacja dotycząca zrównywania czasu przeznaczanego przez kobiety i mężczyzn na wypoczynek. McLean, analizując krytycznie ten aspekt, zauważa, że praca może być rozdystrybuowana pomiędzy klasy i pomiędzy same kobiety właśnie, nie doprowadzając do zwiększenia udziału mężczyzn w wykonywaniu obowiązków domowych. Z drugiej strony popyt na tego typu prace może znacznie się obniżyć w wyniku przyznawania wykonującym je osobom BDP, albo ich cena może znacznie wzrosnąć, tym samym wymuszając większe zaangażowanie mężczyzn w prace domowe (McLean 2015, 8-9). W przypadku kolejnego założenia - równego szacunku - prace tradycyjnie wykonywane przez kobiety, takie jak opieka czy działalność społeczna, mogłyby zostać dostrzeżone i dowartościowane, o ile towarzyszyłaby im odpowiednia, promująca je polityka społeczna. Szacunek zyskałyby także pracownice i pracownicy seksualni, gdyż BDP uwolniłby ich od przymusu podejmowania pracy w branży erotycznej, szczególnie w warunkach zagrażających ich życiu i zdrowiu, a tym samym pracę seksualną świadczyłyby te osoby, które ja świadomie wybrały. Ostatnie dwie reguły, przeciwdziałanie marginalizacji i androcentryzmowi związane są z wcześniej wspomnianym modelem „uniwersalnego opiekuna” Fraser, który to model nie esencjalizuje kobiet i nie zamyka ich w przestrzeni prywatnej, a raczej zachęca zarówno kobiety, jak i mężczyzn do podejmowaniu pracy zawodowej i dzielenia się opieką na równych zasadach. Ten argument stanowi sedno BDP jako propozycji feministycznej, który w związku ze swoja bezwarunkowością (brakiem związku z uczestnictwem w rynku pracy i w pracach domowych) nie działa na rzecz utrwalania tradycyjnego porządku płci. Naturalnie zmianę tego porządku wzmocniłyby dodatkowe działania rządu na rzecz równości, takie jak opieka instytucjonalna, edukacja równościowa oraz walka ze stereotypami (Gheaus 2008), lecz oponenci wskazują, że niosłoby to ze sobą duże koszty, które i tak byłyby znaczące w przypadku wprowadzenia 
BDP. Koszty te jednak można również postrzegać jako inwestycje w gospodarkę przyszłości, opartą na dobrostanie wszystkich mieszkanek i mieszkańców, równości, wolności, partycypacji, znaczeniu i równowadze ekologicznej, na które to inwestycje powinny znaleźć się fundusze.

Istnieje wiele propozycji finansowania bezwarunkowego dochodu podstawowego, choćby omówione przez Bartosza Mikę (2014) czy Macieja Szlindera (2017a): zniesienie transferów socjalnych, podniesienie podatków, zwiększenie deficytu budżetowego czy zwiększenie wpływów w związku z podwyższoną konsumpcją (i tym samym dochodami do budżetu z tytułu podatków, np. VAT) w wyniku wprowadzenia BDP. Samuel Alexander proponuje obok BDP, czyli „dochodowej podłogi”, równoczesne wprowadzenie pułapu dochodu maksymalnego, czyli „dochodowego sufitu”, tak aby redystrybucja dochodów umożliwiła stworzenie bardziej demokratycznego i egalitarnego społeczeństwa, niż kiedykolwiek pozwolił na to kapitalizm (Alexander 2015, 147). Według jego propozycji podatek nałożony na każde dodatkowe dochody (również z kapitału) przekraczające pułap dochodu maksymalnego wynosiłby 100 procent. Dzięki temu stratyfikacja społeczna nie byłaby tak wszechobecna, a różnice pomiędzy najbogatszymi i najuboższymi przestałyby się pogłębiać, jak ma to miejsce obecnie (por. Piketty 2015). Progresywne skale podatkowe, zawierające wiele przedziałów dochodowych z pewnością również pomogłyby w osiagnięciu tego celu. Inne pomysły na finansowanie BDP to tzw. podatek Robin Hooda (mylony często z podatkiem Tobina, który dotyczy jedynie wymiany walut), czyli pobór podatku w wysokości średnio 0,05 procenta od wszystkich transakcji finansowych (handlu akcjami, obligacjami, walutami i derywatami) (Schulmeister 2008). Rozwiązanie to było już dyskutowane w Parlamencie Europejskim, a po wyjściu Wielkiej Brytanii - największego przeciwnika tego podatku - z Unii Europejskiej (UE) jego wprowadzenie będzie całkiem prawdopodobne. Podatek ten ograniczyłby ryzykowne inwestycje i przyczyniłby się do bardziej stabilnego zarządzania funduszami. Płacąc go od obrotu dużymi sumami pieniędzy - np. pożyczonym miliardem dolarów, bo w takim przypadku podatek wynosiłby 50 milionów dolarów inwestorzy zastanowiliby się dwa razy, zanim podjęliby ryzykowną decyzję zakupu bądź sprzedaży instrumentów finansowych. Tym samym niebezpieczne zachowania spekulantów stałyby się rzadsze, przyczyniając się do większej stabilizacji rynków. Sylvia Walby (2015), nawiązując do ostatniego kryzysu finansowego, proponuje mechanizmy wzmocnienia państw UE, które zyskałyby dodatkowe dochody do budżetu, gdyby uszczelniły system podatkowy, np. zakazując operacji na terenie danego kraju firmom, które zarejestrowane są w tzw. rajach podatkowych, nie zatrudniaja na umowach o pracę lub unikaja płacenia podatków (nie płaca ich lub płaca zaniżone stawki). Podatki są źródłem dochodu na rzecz przyszłych inwestycji społecznych, m.in. takich jak BDP, nie zaś jedynie obciążeniem dla społeczeństwa - i tak też powinny być postrzegane. Kolejnym źródłem dochodów byłoby z pewnością 
podniesienie podatku od osób prawnych, czyli CIT (ang. Corporate Income Tax), lub zrezygnowanie z jego obecnej liniowej formy na rzecz progresji podatkowej. Kolejnym pomysłem byłoby opodatkowanie niezrównoważonych praktyk środowiskowych, tak aby firmy ponosily pełne koszty produkcji (por. James Robertson 1999). Źródła finansowania BDP są istotne także ze względu na to, że tworzą one ramy gospodarki przyszłości. Maciejewska i Marszałek ostrzegaja np. przed niebezpieczeństwem związanym z uzależnieniem finansowania dochodu podstawowego od sprzedaży gazu łupkowego (2014, 186), która to decyzja mogłaby mieć katastrofalne skutki dla środowiska naturalnego. Uważają oni również, że dyskusje na temat BDP nie podważają istniejących wzorów produkcji i konsumpcji. Niewiele mówi się także o zmianie paradygmatu makroekonomicznego, w związku z którą do istniejących wskaźników ekonomicznych włączono by prace nieodpłatne i ich podział, a także alternatywne, kolektywne zarządzanie dobrami i usługami, tak aby gospodarka przyszłości oparta była na etyce troski.

Do tej kwestii nawiązują też Julie A. Nelson i Neva Goodwin, które uważają, że

\begin{abstract}
szerszym, finalnym celem „ekonomii kontekstualnej” jest dobrostan wszystkich ludzi, obecnie i w przyszłości, we wszystkich przyjmowanych przez nich społecznych i ekonomicznych rolach: nie tylko konsumenckich czy producenckich, lecz także obywatelskich, rodzinnych, nauczycielskich, rolach opiekunów i osób poddających się opiece a także otrzymujących inną pomoc (Nelson i Goodwin 2005, 2).
\end{abstract}

Role powyższe zostały wzięte pod uwagę przy projektowaniu eksperymentu z dochodem podstawowym w holenderskim mieście Utrecht (Brown Hamilton 2016). Do eksperymentu, który zaplanowany jest na dwa lata i ruszy po zatwierdzeniu go przez Ministerstwo Spraw Społecznych (Dutch News 2017), wybrane zostanie 250 osób spośród pobierających wcześniej świadczenia, które miesięcznie otrzymywać będą kwotę średnio 960 euro i nie będą zobligowane do podejmowania pracy bądź ubiegania się o nią, jak miało to miejsce wcześniej. Dodatkowo osoby, które podejmą pracę w ramach wolontariatu, otrzymają nadprogramowo 150 euro. Cała grupa beneficjentów zostanie podzielona na sześć podgrup, którym zaoferowane zostaną różne warunki i wysokości dochodu, aby sprawdzić, jakimi motywacjami się kierują $\mathrm{i}$ w jaki sposób określona forma dochodu wpłynie na zmianę ich życia. Dla ekonomistek feministycznych najbardziej interesująca w tym wypadku jest obserwacja różnych typów gospodarstw domowych i zmieniających się w nich ról. Z tej perspektywy znaczenie maja również zmiany w zakresie obciążenia nieodpłatną pracą w odniesieniu do modelu „uniwersalnego opiekuna” Fraser, a także zaangażowanie w prace wolontaryjne i podejmowanie pracy najemnej ( $z$ uwzględnieniem warunków tejże pracy znaczace jest np. odrzucanie nisko płatnych prac lub stawianie wyższych wymagań w związku ze środowiskiem, czasem bądź stosunkami pracy). 
Drugim przykładem jest Finlandia, gdzie spośród bezrobotnych wylosowano 2000 osób, które od 1 stycznia 2017 roku otrzymują dochód podstawowy w miejsce wcześniejszych świadczeń (tym samym jest to jednak dochód warunkowy). Eksperyment ten potrwa dwa lata. Przez ten czas beneficjenci będą otrzymywali 560 euro miesięcznie to bardzo niska kwota jak na wysokie koszty życia w kraju - nawet jeśli znajda pracę. W przyszłości rząd planuje włączyć do grupy beneficjentów niezależne zawody (ang. freelance), w których trudno stworzyć stałe miejsca pracy (The Telegraph 2017). Na wyniki tych dwóch eksperymentów trzeba będzie jeszcze poczekać, ale z pewnością - pomimo wspomnianych wad programów - otwieraja one nowe imaginarium, jeśli chodzi o tworzenie rozwiązań gospodarczych.

Dwa kolejne miejsca na świecie, w których planowane jest wprowadzenie BDP, to kanadyjskie Ontario - pod koniec 2017 roku - oraz Glasgow w Szkocji, gdzie rząd niedawno zatwierdził badanie wykonalności wprowadzenia dochodu podstawowego. Choć nie są jeszcze znane szczegóły dotyczące eksperymentu w Glasgow, BDP cieszy się tam dużym poparciem parlamentu (McFarland 2017). Tymczasem w Kanadzie rząd zabudżetował 25 milionów dolarów kanadyjskich na trzy lata prowadzenia testu. Weźmie w nim udział 2500 osób, które żyjąc w ubóstwie, otrzymywały do tej pory inne świadczenia (tu również będzie to zatem początkowo dochód warunkowy). Jak argumentuje minister Helena Jaczek, problem do tej pory polegał na tym, że otrzymując dochody, osoby bezrobotne traciły prawo do świadczeń (w tym zdrowotnych czy związanych z mieszkalnictwem). Otrzymując dochód podstawowy, którego wysokość ustalono na 1320 dolarów kanadyjskich, czyli 3/4 najniższej ustawowej pensji, będa one mogły podejmować pracę bez lęku przez utrata dodatkowych świadczeń (Jaczek 2017). Tym samym przestaną być postrzegane jako osoby leniwe, które nie poszukują i nie podejmują pracy, niedostrzegające walorów jej wykonywania (w rzeczywistości osoby te często po prostu wpadają w pułapkę ubóstwa przez nieefektywny system opieki społecznej, zniechęcający do aktywności), a otrzymywany dochód będzie dla nich trampoliną umożliwiająca poświęcanie czasu czynnościom, na których najbardziej im zależy. Zwrot ku opiece i etyce troski, a także działalności na rzecz bliskich i społeczeństwa mógłby być w tym przypadku znaczny, szczególnie w dobie uelastycznienia pracy najemnej i niepewności towarzyszącej pracownikom na coraz bardziej sprekaryzowanym rynku pracy.

Opisane powyżej przykłady dają nadzieję na przyszłość, szczególnie że w swoich założeniach upodmiotawiają osoby, które otrzymują bądź otrzymają w przyszłości dochód. Niektórzy ekonomiści jednak przestrzegaja, jak wspomniałam w poprzedniej części artykułu, przed (hiper)inflacja, która może towarzyszyć wprowadzeniu BDP na większą skalę. Tcherneva i Wray (2005) uważają, że istniejący obecnie system walutowy nie jest przygotowany na to, aby wszyscy obywatele otrzymywali bezwarunkowy dochód 
podstawowy, który nie jest uzależniony od wykonywania pracy najemnej, gdyż spowoduje to drastyczne obniżenie wartości waluty. Jeśli faktycznie przyznanie BDP łączyłoby się z wyższą podażą pieniądza w gospodarce, inflacja stanowiłaby poważny problem. Jednakże, jak argumentowałam wcześniej, gdy źródła pozyskiwania funduszy ograniczone zostaną do wskazanych ram, to bez realnego wprowadzenia BDP w gospodarce trudno jednoznacznie stwierdzić, czy faktycznie efekt inflacyjny wystapi. Ostatecznie ekonomia, jako nauka społeczna, podatna jest na idee i doktryny, a dotychczas dominujące w niej teorie spowodowały pogłębiające się rozwarstwienie społeczne, którego świat nigdy dotąd nie doświadczył. Pora podjać działania na rzecz równości, a BDP jest bezsprzecznie krokiem w tym kierunku.

Powyższa analiza wpływu bezwarunkowego dochodu podstawowego na równość płci potwierdza, że mógłby on znacząco oddziaływać na podział prac wykonywanych w gospodarstwach domowych, a także przyczyniłby się do wzmocnienia pozycji kobiet oraz innych grup marginalizowanych na rynku pracy. Przedstawione przykłady rzucaja światło na potencjalne pozytywne zmiany gospodarcze wynikające z BDP, co wynika zarówno z przyjętych w omówionych krajach założeń dystrybucyjnych (m.in. upodmiotowienia beneficjentów programów oraz zapewnienia im większej wolności), jak i zmiany aktualnego paradygmatu tradycyjnych świadczeń państwa opiekuńczego. Jednakże BDP to inwestycja, która wymaga finansowania, a jego źródła także tworzą ramy gospodarki przyszłości, dlatego powinny być zrównoważone i promować ekologicznie praktyki. Gospodarka ta powinna opierać się na etyce troski - nie tylko o innych ludzi, ale też inne gatunki - ograniczając bezustanną ludzką ekspansję i kontrolę nad światem materialnym. W gospodarce przyszłości niematerialne zasoby - takie jak relacje z innymi, z przyroda, czas wolny, muzyka, sztuka, wzajemna pomoc, zaufanie i przynależność - mogą stać się wartościami określającymi dobrostan społeczeństwa. Aby jednak społeczeństwo mogło z tych zasobów w pełni czerpać i cieszyć się nimi, konieczne jest zaspokojenie podstawowych potrzeb biologicznych $-\mathrm{z}$ tej perspektywy BDP byłby najlepszym rozwiązaniem.

\section{Podsumowanie}

Niniejszy artykuł łączy zagadnienia związane $\mathrm{z}$ etyką troski oraz znaczeniem opieki w gospodarce przyszłości z koncepcjami gwarancji zatrudnienia i bezwarunkowego dochodu podstawowego. Obie koncepcje - GZ i BDP - zostały tu przeanalizowane krytycznie z perspektywy feministycznej; wskazano ich atuty, przykłady i plany wdrożeń, a także ich wady oraz zagrożenia związane $z$ ich przyjęciem. Jednocześnie wzbogaciłam tę perspektywę o inne rozwiązania, np. proponowane ograniczenie tygodnia pracy najemnej do 20 lub 21 godzin, stworzenie zrównoważonych pakietów pracy a także wprowadzenie dodatkowych 
polityk gospodarczych i społecznych na rzecz budowy równiejszego społeczeństwa, w tym większej progresji podatkowej i górnego limitu dochodów. Takie propozycje wykroczyłyby poza negocjowanie pozycji pracowników w ramach kapitalizmu i skierowały aktywności społeczeństw ku pozamaterialnym obszarom, co pozostaje w zgodzie z wizją gospodarek post-wzrostu. W takich gospodarkach, choć technologie w dużym stopniu wyręcza nas z przykrych, monotonnych i niewdzięcznych zajęć (w tym domowych), relacje opieki, które nie daja się zautomatyzować, moga znaleźć się w centrum życiowych aktywności i w największym stopniu przyczynić się do poprawy dobrostanu ludzi. Wiele stawianych w tym artykule pytań pozostaje bez odpowiedzi, ale w tym momencie, gdy nie znamy jeszcze wyników eksperymentów z BDP w omówionych krajach, ważne jest to, aby tworzyć nowe utopie (i dystopie), odchodząc od indywidualnie definiowanego sukcesu, a skupiając się na wspólnocie. W ujęciu prefiguratywnym oznaczałoby to dążenie do równości wszystkich członkiń i członków społeczeństwa, szczególnie do równości ekonomiczno-społecznej, a więc i podważanie wszelkich form hierarchii, które prowadzą do stratyfikacji społecznej. Za sprawa takich działań nastapić może przesunięcie horyzontu w kierunku jakości życia i opieki, które sa kluczowe zarówno w przypadku gwarancji zatrudnienia, jak i bezwarunkowego dochodu podstawowego, i w mojej opinii tworza podwaliny gospodarki przyszłości opartej właśnie na etyce troski. 


\section{Wykaz literatury}

Albert, Michael. 2007. Ekonomia uczestniczaca. Życie po kapitalizmie. Tłum. Iwo Czyż. Poznań: Wydawnictwo Bractwa Trojka.

Alexander, Samuel. 2015. "Basic and Maximum Income." W Degrowth. A Vocabulary for a New Era. Red. Giacomo D’Alisa, Federico Demaria i Giorgos Kallis. New York: Routledge.

Appadurai, Arjun. 2016. Banking on Words: The Failure of Language in the Age of Derivative Finance. Chicago: The University of Chicago Press.

Barad, Karen. 2003. "Posthumanist Performativity: Toward an Understanding of How Matter Comes to Matter." Signs 28(3): 801-831.

Benería, Lourdes. 2003. Gender, Development, and Globalization: Economics as if People Mattered. London: Routledge.

Braidotti, Rosi. 2006. "The Ethics of Becoming Imperceptible." W Deleure and Philosophy. Red. Constantin V. Boundas. Edinburgh: Edinburgh University Press.

Braidotti, Rosi. 2014. Po człowieku. Tłum. Joanna Bednarek, Agnieszka Kowalczyk. Warszawa: Wydawnictwo Naukowe PWN.

Brown Hamilton, Tracy. 2016. “The Netherlands' Upcoming Money-for-Nothing Experiment." The Atlantic. June 21.

https://www.theatlantic.com/business/archive/2016/06/netherlands-utrechtuniversal-basic-income-experiment/487883/. [dostęp: 15.05.2017].

Budlender, Debbie i Rhonda Sharp. 1998. How to do a Gender-Sensitive Budget Analysis: Contemporary Research and Practice. Canaberra: Commonwealth Secretariat and Australian Agency for International Development.

Cantillon, Sara. 2013. "Measuring Differences in Living Standards Within Households." Journal of Marriage and Family 75(3): 598-610.

Cornish, Flora, Jan Haaken, Liora Moskovitz i Sharon Jackson. 2016. "Rethinking Prefigurative Politics: Introduction to the Special Thematic Section." Journal of Social and Political Psychology 4(1): 114-127.

D’Alisa, Giacomo, Federico Demaria i Giorgos Kallis [red.]. 2015. Degrowth. A Vocabulary for a New Era. New York: Routledge.

De Henau, Jerome, Susan Himmelweit, Zofia Łapniewska i Diane Perrons. 2016. Investing in the Care Economy - Simulating Employment Effects by Gender in Seven OECD Countries. A Report by the Women's Budget Group. Brussels: International Trade Union Confederation.

[Dutch News] 2017. "Utrecht Hopes to Launch Welfare Experiment with Carrot but no Stick." Dutch News. April 28.

http://www.dutchnews.nl/news/archives/2017/04/utrecht-hopes-to-launch-welfareexperiment-with-carrot-but-no-stick/. [dostęp: 15.05.2017].

Ehrenreich, Barbara i Arlie R. Hochschild [red.]. 2004. Global Woman: Nannies, Maids, and Sex Workers in the New Economy. New York: Holt Paperbacks.

Elson, Diane. 1998. "Integrating Gender Issues into National Budgetary Policies and Procedures: Some Policy Options." Journal of International Development 10: 929-941.

Epstein, Barbara. 2002. "The Politics of Prefigurative Community.” W Cultural Resistance Reader. Red. Stephen Duncombe. London: Verso. 
Esplen, Emily. 2009. Gender And Care Cutting Edge Pack - Overview Report. BRIDGE. Brighton: Institute of Development Studies.

Fisher, Berenice i Joan C. Tronto. 1990. "Toward a Feminist Theory of Caring." W Circles of Care: Work and Identity in Women's Lives. Red. Emily K. Abel i Margaret K. Nelson. Albany: State University of New York Press.

Fraser, Nancy. 1990. "Rethinking the Public Sphere: A Contribution to the Critique of Actually Existing Democracy." Social Text 25/26: 56-80.

Fraser, Nancy. 1994. "After the Family Wage: Gender Equity and the Welfare State." Political Theory 22(4): 591-618.

Fraser, Nancy. 2014. Drogi feminiżu. Od kapitalizmu państwowego do neoliberalnego kryzysu. Tłum. Agnieszka Weseli. Warszawa: Wydawnictwo Krytyki Politycznej.

Gheaus, Anca. 2008. "Basic Income, Gender Justice and the Costs of Gender-Symmetrical Lifestyles." Basic Income Studies 3(3): 1-8.

Gilligan, Carol. 1977. "In a Different Voice: Women's Conceptions of Self and of Morality." Harvard Educational Review 47(4): 481-517.

GUS. 2015. Budżet czasu ludności. Warszawa: Główny Urząd Statystyczny.

Hartmann, Heidi. 1976. "Capitalism, Patriarchy, and Job Segregation by Sex." Signs 1(3): 137169.

Haug, Frigga. 2011. „Perspektywa cztery w jednym. Manifest na rzecz bardziej sprawiedliwego życia". Tłum. Miram Boyer, Maria Skóra. Biblioteka Online Think Tanku Feministycznego. http://www.ekologiasztuka.pl/pdf/f0107haug.pdf. [dostęp: 15.04.2017].

Held, Virginia. 2006. The Ethics of Care: Personal, Political, and Global. Oxford: Oxford University Press.

Jaczek, Helena. 2017. “Canada's Basic Income Experiment - Will it Work?” World Economic Forum. February 2. https://www.weforum.org/agenda/2017/02/canadas-basicincome-experiment-will-it-work. [dostęp: 15.05.2017].

Levine, Judith. 2013. Ain't No Trust How Bosses, Boyfriends, and Bureaucrats Fail Low-Income Mothers and Why It Matters. Berkeley: University of California Press.

Lister, Ruth. 1995. "Dilemmas in Engendering Citizenship." Economy and Society 24(1): 35-40.

Manjarin, Edgar i Maciej Szlinder. 2016. “A Marxist Argumentative Scheme on Basic Income and Wage Share in an Anti-Capitalist Agenda." Basic Income Studies 11(1): 49-60.

Marcuse, Herbert. 1991. Człowiek jednowymiarowy. Badania nad ideologia rozwinietego spoteczeństwa przemystowego. Tłum. Stanisław Konopacki. Warszawa: PWN.

McFarland, Kate. 2017. “Glasgow, Scotland: Basic Income Pilot Feasibility Study Approved by City Council." Basic Income Earth Network. February 21. http://basicincome.org/news/2017/02/glasgow-scotland-basic-income-pilotfeasibility-study-approved-city-council/. [dostęp: 15.05.2017].

McGoogan, Cara. 2016. "This Sewing Robot Could Put Sweatshops out of Business." The Telegraph. September 22.

McKie, Linda, Susan Gregory i Sophia Bowlby. 2002. "Shadow Times: The Temporal and Spatial Frameworks and Experiences of Caring and Working." Sociology 36(4): 897-924. 
McLean, Caitlin. 2015. "Beyond Care: Expanding the Feminist Debate on Universal Basic Income." WiSE Working Paper Series 1, September.

Mika, Bartosz. 2014. „Dochód podstawowy i jego konsekwencje dla świata pracy”. Praktyka Teoretyczna 2(12): 145-170.

NEF. 2010. "21 Hours. The Case for a Shorter Working Week." New Economics Foundation. February 13. http://neweconomics.org/2010/02/21-hours/. [dostęp: 15.04.2017].

Nelson, Julie A. i Neva Goodwin. 2005. "Teaching Ecological and Feminist Economics in the Principles Course". GDAE Working Paper 05-05. Medford: Global Development and Environment Institute, Tufts University.

OECD. 2017. "Productivity and ULC by Main Economic Activity (ISIC Rev.4)."

Organisation for Economic Co-operation and Development. April 2. http://stats.oecd.org/Index.aspx?DataSetCode=PDBI_I4. [dostęp: 15.04.2017].

OPZZ. 2017. „Ryzyka i trendy 2017”. Biuro Prasowe Ogólnopolskiego Porozumienia Związków Zawodowych. 30 stycznia. http://www.opzz.org.pl/-/ryzyka-i-trendy-2017. [dostęp: 20.04.2017].

Peck, Jamie i Nik Theodore. 2007. "Variegated Capitalism." Progress in Human Geography 31(6): 731-772

Phillips, Judith. 2007. Care. Cambridge: Polity Press.

Piketty, Thomas. 2015. Kapitat w XXI wieku. Tłum. Andrzej Bilik. Warszawa: Wydawnictwo Krytyki Politycznej.

Polanyi, Karl. 2010. Wielka transformacja. Polityczne i ekonomicz̧ne źródła naszych czasów. Tłum. Maria Zawadzka. Warszawa: Wydawnictwo Naukowe PWN.

Power, Marilyn. 2004. "Social Provisioning as a Starting Point for Feminist Economics." Feminist Economics 10(3): 3-19.

Rakowski, Tomasz. 2016. „Lokalne formy rozwoju, samoorganizacja i potencjał sprawczy”. Kultura i Rožój 1(1): 89-108.

Robertson, James. 1999. The New Economics of Sustainable Development. A Briefing for Policy Makers. London: Kogan Page.

Robeyns, Ingrid. 2014. „Ingrid Robeyns - Czy dochód podstawowy odda sprawiedliwość kobietom?" Tłum. Maciej Szlinder. Praktyka Teoretyczna. 10 lutego. http://www.praktykateoretyczna.pl/?s=Robeyns. [dostęp: 05.06.2017].

Schulmeister, Stephan. 2008. "A General Financial Transaction Tax Motives, Revenues, Feasibility and Effects." WIFO. http://dx.doi.org/10.2139/ssrn.1714395. [dostęp: 15.04.2017].

Sen, Amartya K. 1993. "Capability and Well-Being." W The Quality of Life. Red. Martha C. Nussbaum i Amartya K. Sen. Oxford: Clarendon Press.

Standing, Guy. 2005. "Why Basic Income Is Needed for a Right to Work." Rutgers Journal of Law \& Urban Policy 2(1): 91-102.

Szlinder, Maciej. 2017. „Dochód podstawowy - instrukcja obsługi”. Wywiad Jakuba Dymka. Krytyka Polityczna. 21 lutego. http://krytykapolityczna.pl/gospodarka/dochodpodstawowy-instrukcja-szlinder/. [dostęp: 05.06.2017]. 
Szlinder, Maciej. 2017a. „Mity w debacie o dochodzie podstawowym”. Bez Dogmatu. Kwartalnik Kulturalno-Polityczny 111(I/2017): 27-31.

Tcherneva, Pavlina R. i L. Randall Wray. 2005. "Common Goals - Different Solutions: Can Basic Income And Job Guarantees Deliver Their Own Promises." Rutgers Journal of Law \& Urban Policy 2(1): 125-166.

[The Telegraph] 2017. „Finland's unemployed to be given basic income of $€ 560$ per month in first such experiment in Europe." The Telegraph January 3.

http://www.telegraph.co.uk/news/2017/01/03/ finlands-unemployed-given-basicincome-560-euros-per-month-first/. [dostęp: 15.05.2017].

Tronto, Joan C. 1987. "Beyond Gender Difference to a Theory of Care." Journal of Women in Culture and Society 12(4): 644-663.

Tronto, Joan C. 1995. "Care as a Basis for Radical Political Judgements.” Hypatia 10(2): 141149.

Ungerson, Clare. 1990. “The Language of Care: Crossing the Boundaries.” W Gender and Caring: Work and Welfare in Britain and Scandinavia. Red. Claire Ungerson. London: Harvester Wheatsheaf.

Ungerson, Clare. 1995. "Gender, Cash and Informal Care: European Perspectives and Dilemmas." Journal of Social Policy 24(1): 31-52.

Walby, Sylvia. 2015. Crisis. Cambridge: Polity Press. 
Zofia Lapniewska - ekonomistka i feministka, adiunktka w Instytucie Ekonomii, Finansów i Zarządzania Uniwersytetu Jagiellońskiego. W latach 2012-2016 przebywała za granica jako podoktorska badaczka m.in. na Uniwersytecie Humboldtów w Berlinie i London School of Economics and Political Science. Jej artykuły były publikowane w takich pismach jak Feminist Economics czy Review of Radical Political Economics.

\section{DANE ADRESOWE:}

Instytut Ekonomii, Finansów i Zarządzania

Uniwersytet Jagielloński

ul. prof. S. Łojasiewicza 4

30-348 Kraków

EMAIL: z.lap@riseup.net

CYTOWANIE: Lapniewska, Zofia. 2017. „Etyka troski a gospodarka przyszłości.” Praktyka Teoretyczna 2(24): 101-122.

DOI: $10.14746 /$ prt.2017.2.4

\section{AUTHOR: Zofia Lapniewska}

TITLE: The Ethics of Care and the Future Economy

ABSTRACT: For decades, economic theories have been changing due to historical events and economic turbulences, yet each time they have had an actual impact on the lives of societies. Today, when neo-liberal theories are no longer appreciated, the divide between the richest and the poorest members of society is growing almost exponentially, and technological development drastically changes working conditions, new visions of a future economy are needed - ones in which everyone can find their place and live a life worth living. My suggestion is that this economy should be based on the ethics of care - a line of argument presented in this article. It opens with an outline of the ongoing economic changes. There then follows an explanation of the importance of ethics of care, as well as of the care necessary for the development and reproduction of societies, as the main framework for further consideration of job guarantee and unconditional basic income, to which the subsequent sections of the article are devoted. The analysis of these theories from a feminist perspective will also be enriched with proposals for additional solutions that go beyond the current paradigm of growth.

KEYWORDS: ethics of care, feminist economics, care, unconditional basic income, job guarantee, future economy. 